\title{
Democratization in the Global South: From democratic transitions to transformative democratic politics
}

\begin{abstract}
Democracy has attained a hegemonic position both as a normative ideal and as the dominant form of government, but there are growing concerns about democratic decline and crisis. The numerical growth of democracies has slowed down and there have been some reversals from democratic to authoritarian rule in recent years. Nevertheless, the primary concern is about the substance of formal democracies, especially as recent democratic transitions have tended to produce depoliticized democracies and hybrid forms of rule rather than substantive democracy. This article uses the growth and decline of democracy as an occasion to review the current state of democracy in the world; discuss the links between the modality of democratic transition and problems of post-transition democratic substance, and; examine competing approaches to democratic deepening. A case is made for shifting the perspective on democratization, from democratic transitions to the open-ended politics of substantial democratization. This means that the analytical approach should be broadened from elitist institutional design for electoral democracy to transformative democratic politics. The article presents this line of argument and provides brief illustrations based on recent transitions in the Global South.
\end{abstract}

Keywords: democratization, democratic transition, electoral democracy, substantive democracy, substantial democratization, transformative politics 


\section{Introduction}

Contemporary debates on democratization and democracy are marked by a striking paradox: While a large number of democratic transitions in recent decades means that democracy has attained a global hegemonic position - both as a normative ideal and as the dominant form of government - there are also growing concerns about democratic decline and authoritarian resurgence (Carothers \& Youngs, 2017; Diamond \& Plattner, 2015; Schmitter, 2015; Zakaria, 2007). Political and institutional weaknesses and decay are increasingly recognized in both old and new democracies, giving rise to a discourse where "democracy itself appears to be unraveling - helped along by resurgent authoritarianism, weakened liberal democratic values, rising populism, and contagious illiberalism" (Carothers \& Youngs, 2017). While Carothers and Youngs argue that such representations tend to overstate negative trends and overlook positive developments, these tendencies and discourses call for critical scholarly attention.

The present article uses the growth and decline of democracy as an occasion to (i) review the current state of democracy in the world; (ii) discuss the links between the modality of democratic transition and problems of post-transition democratic substance; and, (iii) examine competing approaches to democratic deepening. A case is made for shifting the perspective on democratization, from democratic transitions to transformative democratic politics. This means that the analytical approach should be broadened from elitist institutional design for electoral democracy to the continuous and open-ended politics of substantial democratization.

The article provides, first, a brief and general review of the changing state of democracy since the 1970s, based on aggregate data from international democracy assessments. Democracy observers commonly report that this period has seen a global hegemonic rise of electoral democracy, but the numerical growth of democracies has slowed down and there have also been some reversals from democratic to authoritarian rule (Freedom House, 2018; The Economist, 2017). The foremost concern is, however, not the number of democracies, but the limited substance of formal democracies. The current crisis of democracy is thus about the widening gap between the ideals and realities of democratic rule (Schmitter, 2015). 
Second, this review of the global state of democracy is followed by a section that considers one key explanation behind the problem of democratic substance, namely the links between the modality of transition and post-transition outcomes. The core argument is that the dominant actors in recent transitions have institutionalized formal democratic participation and representation, but in a manner that limits substantive democratic control of public affairs. This has produced depoliticized democracies and hybrid regimes rather than substantive democracies.

Based on these democratic shortcomings, the third section focuses on competing approaches to democratic deepening. A case is made for a relational and gradual perspective on state and society. This represents a broadening of the analytical and political agenda, from elitist institutional design for electoral democracy to transformative democratic politics. While human geographers have paid little attention to democratic institutions and transitions, there are numerous studies of popular movements and contentious politics. Human geography may thus also have much to offer for the agenda of transformative democratic politics.

\section{The hegemonic rise and decline of democracy}

The three decades from the mid-1970s to the mid-2000s saw a rapid growth in the number and proportion of countries and people that have some form of democratic government, what has come to be known as the third wave of democracy (Huntington, 1991). Measurements of this wave vary, however, according to the definitions and indicators that are being used. If democracy is defined in a Schumpeterian way as "institutional arrangement for arriving at political decisions in which individuals acquire the power to decide by means of a competitive struggle for the people's vote" (Schumpeter, 1942, p. 269), then it follows that the period since the mid-1970s has seen a large growth of democracies. IDEA (2017), for example, finds that the proportion of electoral democracies rose from $30 \%$ in 1977 to $68 \%$ in 2016 (figure 1). The increase was especially rapid from the mid-1970s to the mid-90s, but the number and proportion of democracies continued to rise also thereafter. Although there have been some democratic reversals and one-third of the countries remains under 
authoritarian rule, including major powers such as China, Egypt, Russia and Saudi Arabia, this does not mean that there has been a global decline of electoral democracies.

In addition to the institutional arrangements for elected government, democracy is often assessed through the status of civil and political rights and liberties. The Freedom House, for example, emphasizes the rights and freedoms enjoyed by individuals, in agreement with the Universal Declaration of Human Rights. Their annual reports show that the number of countries that can be considered free increased from 43 out of 150 countries (28,7\%) in 1972, to 90 out of $193(46,6 \%)$ in 2007 (Freedom House, 2018) (Figure 1). At the same time, the number of partly free countries rose from $38(25,3 \%)$ in 1972 to $60(31,1 \%)$, while the number of not free countries declined from $69(46,0 \%)$ to $43(22,3 \%)$.

Whereas the indicators and classification systems are varied, the mainstream democracy surveys support the conclusion that democracy attained a hegemonic position in the fourth quarter of the 20th century. The last decade, in contrast, has been dominated by discourses on democratic decline and crisis. Since 2007 the annual democracy assessments from Freedom House and The Economist have continuously reported democratic decline. The Freedom House (2018, p. 1) observes that "for the 12th consecutive year (...), countries that suffered democratic setbacks outnumbered those that registered gains". Likewise, The Economist (2017) reports that the number and percentage of countries and the proportion of the world population in full democracies have decreased, while the figures for flawed democracies and hybrid regimes have increased. The CIVICUS State of Civil Society 2018 similarly observes that 119 countries have closed, repressed or obstructed civic space and that the space for civil society is now coming under attack in countries where it has rarely happened before (CIVICUS, 2018).

The question about the state of democracy gets more complicated if democracy is defined in a more substantive manner. IDEA (2017) provides a more nuanced interpretation based on Beetham's (1999) substantive definition of democracy as "popular control over public decision-making and decision-makers, and political equality between citizens in the exercise of that control" (IDEA, 2017, p. 5). This is operationalized through five main attributes of democracy: representative government; fundamental rights; checks on government; impartial 
administration; and, participatory engagement. IDEA's approach is thus designed to capture key aspects of popular control and political equality beyond the institutional arrangements for civil and political freedoms or electoral democracy.

The methodology employed by IDEA supports the general conclusion that the current situation is more positive than suggested by the Freedom House (2018) and The Economist (2017). IDEA (2017) finds that the last decade has been characterized by trendless fluctuations rather than a marked democratic decline. There is, however, one notable exception to this pattern: There is little evidence of any major improvements in impartial administration at the aggregate level, and this seems to be the core of growing frustration with democracy since "corruption, discrimination and ineffectiveness make citizens feel that democracy does not deliver the basic services and equal treatment that they request, and the human rights to which they are entitled" (IDEA, 2017, p. 27). This means that while electoral institutions may function reasonably well as a formal basis for elected governments, they often fail to produce substantive outcomes.

The argument that can be derived from such democracy assessments is that the current crisis of democracy is about the substance rather than the number of democracies. While the IDEA assessment highlights problems of public administration on the output side of democracy, others emphasize the depoliticization of public affairs and the weakening of popular representation and control in democratic decision-making (Harriss, Stokke, \& Törnquist, 2004; Törnquist, Webster, \& Stokke, 2009). Within human geography this is especially found as discourses on post-political governance, for example in regard to cities, natural resource extraction and development (Bridge, 2008; Glassman, 2007; Paddison, 2009; Swyngedouw, 2004). The general argument is that governance has taken on a cross-cutting post-political form in both old and new democracies. Such hollowing-out of democracy on both the input side and output side combined with social dislocations under neoliberal globalization yield conducive conditions for right-wing populism, which is often identified as a contemporary challenge for both old and new democracies (Brubaker, 2017; Hadiz \& Chryssogelos, 2017; Kriesi \& Pappas, 2015). The argument is thus that depoliticization of public affairs, weak popular representation and technocratic decision-making undermines the substance of democracy amidst a global hegemonic rise of electoral democracy. 


\section{The modality and outcomes of democratic transitions}

Limited democratic substance - in the context of economic globalization and neoliberal governance - is a contemporary challenge in both old and new democracies, but seems especially acute in states that have undergone recent transitions in the global south (Stokke \& Törnquist, 2013). Many of these have been formal and minimalist democracies from the beginning as a consequence of their mode of transition from authoritarianism, while also being strongly influenced by neoliberal discourses and development strategies that limit the range of public affairs that are subjected to democratic government. This impact of democratic transition on post-transition governance remains under-researched within human geography. Whereas geographers have paid close attention to neoliberal governance, less has been said about its relationship to contemporary forms of democratization (Barnett \& Low, 2004; Stokke, 2009). The following paragraphs thus reviews the links between the modes and outcomes of transitions from authoritarianism, as a basis for discussing transformative politics of substantial democratization in the next section.

The modality of democratic transitions has important implications for post-transition democratic substance. In contrast to earlier democratization processes, recent transitions are often described as democratization without preconditions, meaning that they cannot be explained with reference to structural changes in society (Grugel \& Bishop, 2014; Haggard \& Kaufman, 2016; Mahoney \& Snyder, 1999). The earlier political history of democratization gave rise to theories that emphasized economic development, modernization and class transformation as preconditions and explanations for democratization (Lipset, 1981; Moore, 1966; Rueschemeyer, Stephens, \& Stephens, 1992). Recent transitions have, in contrast, shown that democracy can emerge under highly diverse conditions (Munck, 2015). What matters most, it is argued, is not the structural preconditions but the strategies and capacities of key political actors (Grugel \& Bishop, 2014). The third wave of democracy has thus given rise to a new transition perspective that emphasize political agency and contextual politics more than economic and social structures (Linz \& Stepan, 1996; O'Donnell \& Schmitter, 1986). 
It follows from this attention to political agency that democratic transitions may follow multiple paths from authoritarianism and yield varied outcomes. Schmitter and Karl (1991) famously construct four ideal type modes of transition (table 1), based on the social character of actors who drive the transition process (elites vs. mass actors) and the general strategies they employ (negotiated compromises vs. use of force), while Munck and Leff (1997) draw additional attention to the path-dependent character of transition processes. Within this ideal typical classification scheme, earlier democratization processes are portrayed as bottom-up and driven by popular socio-political movements. This created political reforms through negotiations and compromise or political revolutions through the use of force, as illustrated by the historical democratization processes in the UK and France (Schmitter, 2017).

Most democratic transitions since the mid-1970s, in contrast, have come from above (Schmitter, 2017). They reflect the interests, strategies and interactions among political elites, who engage in designing institutions for electoral democracy and thereby create a framework for post-transition politics (Munck \& Leff, 1997). Such transitions have either been imposed by autocratic elites without any negotiations with oppositional elites, or they have been based on negotiated pacts between soft-liners within the authoritarian regime and moderate pro-democracy elites. In both imposed and pacted transitions, a key factor is said to be the internal division within the authoritarian regime between reformist soft-liners and reformresistant hardliners. The principal difference is whether softline autocrats and moderates in the opposition negotiate a pact to reduce the uncertainty of a regime transition and its outcomes (Schmitter, 2017).

The literature on modes of transition grew out of the experiences of democratization in Southern Europe, Latin America and Eastern Europe from the mid-1970s to the mid-90s (Linz \& Stepan, 1996; Munck \& Leff, 1997). This broad diversity of cases was portrayed as varieties of elite negotiated transitions. The same interpretative framework was subsequently applied to transitions from authoritarian rule in Sub-Saharan Africa and a much smaller number of cases in Southeast Asia. For example, the transitions in the 1990s from apartheid in South Africa and from authoritarian rule under President Soeharto in Indonesia have been portrayed as negotiated transitions (Fukuoka, 2014; Guelke, 2007). Closer inspection of these 
cases reveals, however, a more complex and multi-layered causation, where for example economic crises and popular struggles for social justice and democracy produced conditions that shaped subsequent negotiations on political freedoms and democratic institutions (see f.ex. N. Alexander, 2002; Aspinall, 2005; Marais, 2001; Robison \& Hadiz, 2004; Seekings, 2000). Such insights and debates have led democratization scholars to search for more complex explanatory models that combine structural, institutional and agency approaches (Grugel \& Bishop, 2014; Mahoney \& Snyder, 1999; Rueschemeyer et al., 1992). It is nevertheless the negotiated transition that is seen as the archetype of the recent wave of democratization and remains the foremost analytical reference point, even though transition scholars also acknowledge that the third wave of democratization contain a broad diversity of pacted transitions as well as important examples of imposed transitions (Linz \& Stepan, 1996; Munck \& Leff, 1997; Schmitter \& Karl, 1991; Stradiotto \& Guo, 2010).

Myanmar's recent transition from authoritarian rule provides an illustrative example of how this general discourse on modes of transition frames contextual scholarly and political discourses, and thus also international diplomatic and activist engagement strategies. After five decades of military rule, Myanmar has seen a democratic opening since 2010, when a flawed election was used to transfer power to a nominally civilian government that opened up for basic civil freedoms and electoral democracy (Cheesman, Skidmore, \& Wilson, 2012). This has generated scholarly and political debates about the dynamics and outcomes of the democratic opening, especially whether Myanmar is in transition to liberal democracy or to institutionalized semi-authoritarianism (Cheesman, Farrelly, \& Wilson, 2014; Egreteau, 2016; Lall, 2016).

On the one hand, the first years of transition was dominated by a discourse that sees Myanmar's democratic opening as a negotiated transition to democracy, where the main driving force has been an alliance between the reformist government led by President Thein Sein (2011-2016) and a group of engagement-oriented civil society actors supported by Western aid donors (Lall, 2016). The overall strategy of this reform alliance was to incorporate the pro-democracy and pro-federalism opposition forces into parliamentary politics under the military-designed 2008 Constitution. This created a discursive and political divide between what was portrayed as engagement-oriented softliners and engagement- 
averse hardliners (Pedersen, 2014; Stokke, Vakulchuk, \& фverland, 2017). On the other hand, an alternative discourse has gained ground in recent years and portrays Myanmar's democratic opening as a military strategy to institutionalize a hybrid form of rule, in order to maintain political stability and military power with increased domestic and international legitimacy (Bünte, 2013; Huang, 2013; L. Jones, 2014). A core element in this strategy is the military-designed 2008 Constitution, which provides a framework for a unitary state with formal democracy and guaranteed positions of power for the military in parliamentary politics, government and public administration (Egreteau, 2016). Proponents of this interpretation also point to the importance of geopolitics in Southeast Asia, arguing that the military regime and Western states had a mutual interest in re-engaging each other in the context of a "rising China", and that this gave increased legitimacy for the military even without substantive political reforms (Bünte \& Dosch, 2015; Egreteau \& Jagan, 2013). The argument is thus that Myanmar's democratic opening should be understood as an imposed transition that institutionalizes a hybrid form of rule (Stokke et al., 2017).

Such theoretical and contextual debates raise critical questions about the dynamics of democratization but also about the links between the modality of transition and the outcomes in terms of democratic substance. Munck and Leff (1997, p. 343) thus observe that different modes of transition "shape the post-transitional regime and politics by affecting the pattern of elite competition, institutional rules crafted during the period of transition, and disposition of key actors to accept or reject the new rules of the game." There is a rich literature that provides qualitative contextual analyses of the links between democratic transitions and the substance of post-transition democracy. They typically find that countries that have moved away from authoritarian rule have not achieved well-functioning liberal democracy, but have instead come to be known as democracies with adjectives, for example described as formal, electoral, illiberal, minimalist, clientelist, semi-authoritarian, oligarchic or guided democracies (Carothers, 2002; Collier \& Levitsky, 1997; Ottaway, 2003). To simplify this classificatory complexity, a heuristic distinction can be made between hybrid regimes and depoliticized democracies.

Hybrid regimes, on the one hand, can be described as systems that contain basic civil and political liberties and institutional arrangements for competitive elections, but also 
authoritarian restrictions and pressure on the opposition, civil society, media, the public administration and the judiciary. Ottaway (2003, p. 3) describes semi-authoritarian democracies as "ambiguous systems that combine rhetorical acceptance of liberal democracy, the existence of some formal democratic institutions, and respect for a limited sphere of civil and political liberties with essentially illiberal or even authoritarian traits". Levitsky and Way (2010) similarly use the term competitive authoritarianism to refer to systems that have constitutional arrangements for electoral democracy while incumbent abuse of state power violates civil liberties and free and fair elections. Ottaway (2003) adds that semi-authoritarian regimes are deliberately designed and carefully maintained alternatives to democracy. Such regimes can thus be seen as calculated outcomes of strategies whereby an autocratic regime concede to electoral democracy but maintain institutional safeguards against radical transformations that would be to their disadvantage (Slater \& Wong, 2013).

The aforementioned transition in Myanmar can for example be seen as a strategically imposed and institutionalized semi-authoritarian form of rule (Egreteau, 2016; Stokke et al., 2017). This mode of transition has institutionalized a hybrid form of rule where there are new and important democratic spaces, but where the substance of democracy is curtailed by constitutional regulations that guarantee the military positions of power and limits the civilian control of the military. The hybrid character of the regime is especially visible in the current co-existence of a democratic government led by State Counsellor Aung San Suu Kyi and the National League for Democracy (NLD), and constitutional provisions that guarantee the military positions of power in parliament, government and public administration and thus limit the prospects for further state reforms in support of substantive democracy, peace and citizenship (Blaževič, 2016; Zin, 2016).

Depoliticized democracies, on the other hand, can be described as institutionalized electoral democracies where policy-making and implementation are depoliticized rather than under substantive popular control (Harriss et al., 2004; Wilson \& Swyngedouw, 2014). Governance of public affairs is typically dominated by market and network models that limit the issues that come under democratic control and govern them in a post-political manner (Flinders \& Wood, 2015). The definition of demos is often found to be restricted and political inclusion is 
characterized by top-down incorporation that render people as subjects of governance rather than sovereign citizens (Chatterjee, 2004). And the political parties and civil society organizations that are the prime mediating links between people and politics are often organizationally weak and have little capacity to represent constituencies, formulate political alternatives and hold governments to account (Carothers, 2006; Houtzager \& Gurza Lavalle, 2010; Randall, 2007). This means that the democratic chain from people, through direct participation or mediated representation, to governance of public affairs can be said to be depoliticized at all levels (Törnquist et al., 2009).

Post-Soeharto Indonesia may serve as an illustrative case. Its mode of transition was marked by internal fragmentation of the authoritarian alliance related to over-concentration of economic and political power, culminating in regime change in a context of financial crisis and pro-democracy mass mobilization in the late 1990s (Aspinall, 2005; Fukuoka, 2014; Robison \& Hadiz, 2004). This particular mode of transition resulted in de-concentration of power through institutional arrangements for democracy, decentralization and civilian control of the military (Aspinall \& Mietzner, 2010). Indonesia has thus been portrayed as an example of a successful democratic transitions. Critical observers have, however, noted that contemporary Indonesia is still marked by oligarchic control of the economy and politics, combined with topdown political incorporation of people through clientelist and populist means rather than bottom-up political integration (Ford \& Pepinsky, 2014). Indonesia can thus be said to represent a post-transition society that is characterized by institutionalized democracy, but where decision-making and policy implementation on public affairs are depoliticized rather than under effective popular control (Aspinall \& Mietzner, 2010; Samadhi \& Warouw, 2009; Törnquist, 2013).

This brief review supports the general argument that recent transitions have tended to produce hybrid regimes and depoliticized democracies. Summing up 25 years of transition studies, Schmitter (2010) finds that democratization has proven far easier to accomplish than expected, but that democratic transitions have also been less consequential than what was anticipated. While there was a common expectation that democratization would bring "significant changes in power relations, property rights, policy entitlements, economic equality, and social status" (Schmitter, 2010, p. 19), he concludes that the elitist transitions 
since the 1970s have accomplished far less than mass-based democratization in the past. This supports the argument about causal links between elitist modes transition and post-transition problems of democratic substance. Recent transitions have produced relatively stable electoral democracies but many of them have had less consequence for non-elite beneficiaries than what was anticipated, and this may also explain why this kind of democratization has been relatively easy to achieve.

\section{Substantial democratization through transformative democratic politics}

A core assumption in studies of democratic transitions is that any country moving away from authoritarian rule is in transition to democracy. Many transitions in recent decades have, however, not produced well-functioning democracies, but have ended up somewhere between authoritarian and democratic rule. Transitologists have often considered this a temporary problem as democratic consolidation is said to take time. Carothers argues, in contrast, that such in-betweenness should be understood as a relatively stable grey zone where states "are neither dictatorial nor clearly headed toward democracy" $(2002$, p. 9). This situation raises critical questions about the prospects and dynamics of more substantial democratization, which may be defined as a process towards fulfilment of the democratic principle of popular control of government based on political equality (Beetham, 2017). Such substantial democratization requires institutionalization of substantive representation and democratic control of public affairs, but also implies substantive gains on the output side of democracy. Scholarly and political debates offer different answers to how these transformations may come about, with a general divide between state- and society-centered approaches to democratic deepening.

State-centered approaches, on the one hand, emphasize the importance of building strong state institutions to foster democratic politics and contain forces that may threaten the stability of new democracies. There are, however, divergent views on which institutions should be given first priority. The elitist crafting of democratic institutions during the third wave of democracy prioritized building the basic institutions of electoral democracy (Carothers, 2007a; Mahoney \& Snyder, 1999). This approach was based on assumptions 
about the pre-existence of a functioning state and that democratic elections would yield democratic political practices and transform conflict-ridden societies (Grugel \& Bishop, 2014). These assumptions have been met with growing skepticism and increased attention to statebuilding in democracy studies and international democracy assistance (Sisk, 2013).

The contemporary attention to state-building is rooted in discourses about state fragility and failure, which legitimizes interventions to strengthen state authority and political stability (Call, 2008; Jarstad \& Sisk, 2008; Paris, 2004). Mansfield and Snyder (2007a, 2007b) thus argue that democratization should be sequenced in the sense that institutions to secure political stability and rule of law should precede political liberalization in order to reduce the likelihood of destabilizing social protests and conflicts (see also Fukuyama, 2014; Paris \& Sisk, 2009). In this context, it can also be observed that developmental state capacity building has gained increased attention among aid donors, as a strategic intervention to create conducive conditions for peace and democracy in conflict-ridden societies (Carothers \& De Gramont, 2013; Chandler, 2010; Duffield, 2001).

Such state-centered approaches and arguments thus promote institution-building as the primary intervention strategy for democratic deepening while paying less attention to democratizing actors and agendas in society. While these positions have been the subject of much debate in political science and international relations, human geographers have had less to say about statebuilding. The foremost exception is political geographic analyses of the geopolitics of war and peace in conflict-ridden states in the Global South (see for example Flint, 2005; Ingram \& Doods, 2016; Kobayashi, 2012).

Society-centered approaches, on the other hand, emphasize antagonisms and mobilizations in society as the foremost source of democratic deepening. This perspective includes the liberal position that democratic consolidation requires a vibrant and autonomous civil society to ensure transparency, accountability and legitimacy of the state and governance (Edwards, 2011; Mercer, 2002; Ottaway \& Carothers, 2000). It also contains more radical approaches that foreground antagonistic relations and contentious politics of citizenship by social movements, trade unions and joint alliances (della Porta \& Diani, 2015; Holston, 2009; Stokke, 2017; Tilly \& Tarrow, 2007; Van der Heijden, 2014). 
Such struggles over diverse forms of justice - cultural recognition, social redistribution and political representation - are seen as alternative modes of bottom-up politics when conventional forms of representation are found to be top-down and ineffective (della Porta \& Diani, 2015). "New" social movement politics has thus been contrasted with the "old" politics of political parties, which is conventionally deemed to be the principal mediator for democratic representation but is often more reflective of dynamics in the political field than grievances and interests in society. This critique seems especially strong in post-transition societies where parties are typically found to be new, poorly institutionalized and electoralist from the beginning (Carothers, 2006; Randall \& Svåsand, 2002; Tomsa \& Ufen, 2013; Webb \& White, 2009). In this situation, the alternative politics of social movements is held to be crucial for representing identities and interests in society and thus building more substantive or radical democracy (Laclau \& Mouffe, 1985; Smith, 1998). Society-centered perspectives thus prioritize contentious politics but pay less attention to state institutions and how popular forces not only engage with the state but also build and transform democratic institutions.

While human geographers have had relatively little to say on state-building and formal democratization, they have contributed actively to the growing literature on the spatiality of movement politics (see f.ex. Leitner, Peck, \& Sheppard, 2006; Nicholls, Miller, \& Beaumont, 2013). These studies have typically examined the emergence and strategies of individual movements, with special attention to their political opportunities, mobilization structures, cultural framing and repertoires of protest. Movement studies have increasingly turned to the notion of contentious politics to emphasize political interactions and contentions among diverse forces and their outcomes. This represents an analytical shift from political spaces as an external context for activism to studies of how actors understand, act on and shape institutional and discursive spaces (Gleiss, 2017). Within development geography, the former mode of inference is illustrated by studies of how development projects and neoliberal governance construct invited spaces for participation with a strategic selectivity for different actors, interests and strategies. This is counter-posed to studies of how social movements invert or invent political spaces to achieve more substantive participation (Cornwall, 2004, 2011; Hickey \& Mohan, 2004; Millstein, 2017; Miraftab \& Wills, 2005; Mohan, 2007; Wafer \& Oldfield, 2015). 
Social movement studies have thus demonstrated the importance of collective struggles for citizenship across diverse issues and contexts, but also identified common problems of fragmentation and limited political capacity (Haarstad, 2007). The two examples of supposedly successful pacted transitions that were mentioned earlier - South Africa and Indonesia - have for example been marked by vibrant post-transition citizens' movements. In South Africa this has primarily taken the form of everyday politics and movements for socioeconomic rights, mirroring the dual focus on democracy and social justice in the antiapartheid movement and the continued problems of social injustices after the democratic transition (P. Alexander, 2010; Ballard, Habib, \& Valodia, 2006; P. Jones \& Stokke, 2005; Jordhus-Lier, 2013; Millstein, 2017). Post-Soeharto Indonesia has likewise seen the growth of diverse social movements that politicize questions of cultural, social and environmental justice (Hiariej \& Stokke, 2017; Priyono \& Törnquist, 2003).

While these movements have been important for expanding citizenship, they face challenges in building coherence and capacity across diverse subject positions, experienced injustices and mobilizations. In contrast to earlier struggles against authoritarianism in both South Africa and Indonesia, there is no coherent movement or program that provide an organizational or discursive node for polycentric politics of citizenship, nor is there a basis for arguing that the diversity of activism is bound together in a shared project of counterhegemonic resistance, as implied in the notion of a polycentric multitude (Ballard et al., 2006; Hiariej \& Stokke, 2017). The state is a common focal point for making claims, and it could be argued that it is an arena for integrating and transforming antagonistic relations into agnostic politics, as argued by Mouffe $(2005,2013)$. However, this requires a democracy that offers well-functioning institutions for political representation and decision-making. In South Africa and Indonesia, as in many other new democracies, it is often found that formal democracy is underperforming in this respect. It is thus a foremost concern to transform democracy itself, also as a means for transforming structures of injustice in society (Stokke \& Törnquist, 2013).

The bifurcation between state- and society-centered perspectives and the limitations of both draw attention to the need for relational state-society approaches to democratic deepening. This implies an understanding of democratization as a continuous and gradual process based 
on cumulative interrelations between democratic institutions and democratic politics (della Porta, 2013). In response to the statebuilding agenda, Carothers thus advocates gradualism rather than sequencing as a general approach to democratization, where "the gradualist approach seeks to find a way for countries where few circumstances favor democratization to take incremental but definite steps toward open political competition while simultaneously pursuing state-building and rule-of-law reforms" (Carothers, 2007b, p. 21, italics in original). Focusing on the limitations of popular movements, Stokke and Törnquist similarly argue that there is a need for transformative democratic politics, defined as "political agendas, strategies and alliances that use formal and minimalist democracy to introduce politics and policies that may enhance people's opportunities for improving democracy and making better use of it" (2013, p. 3). This approach thus highlights the role of engagement with the institutional spaces of formal democracy, both to influence policy processes and to institutionalize widened spaces for participation and representation (Berman, 2006).

The notion of transformative democratic politics emphasizes the political interests, strategies and capacities of popular movements but acknowledge that civil society actors are often hampered by lack of capacity and limited access to institutional political spaces (Haarstad, 2007). This means that successful transformative politics require the building of common agendas and organizational alliances among civil society organizations, trade unions and political parties, to ensure political influence and institutionalization of more substantive representation and participation (Haarstad, 2007; Hiariej \& Stokke, 2017). Such alliances and transformative strategies are often found to be challenged in the contemporary context of minimalist democracy and neoliberal governance. They have, however, been decisive in the making of celebrated examples of more substantive democracy at both national and local scales, including for example the historical emergence of social democracies in Scandinavian countries as well as recent examples of participatory local democracy in Brazil, India and elsewhere (Baiocchi, 2003, 2005; Berman, 2006; Brandal, Bratberg, \& Thorsen, 2013; Fung \& Wright, 2003; Heller, 2013).

Sandbrook et al. (2007), for example, identify prominent examples of social democratic states in Asia, Africa and Latin America and argue that they are products of broad movements engaging with and building democratic developmental institutions. Heller (2013) similarly 
observe that the paradigmatic examples of local popular democracy in Porto Alegre (Brazil) and Kerala (India) are neither the outcome of institutional design by committed political elites nor the product of civil society activism alone. Their characteristics and dynamics should rather be understood as the outcome of an interplay between activism in civil society and mass-based political parties with access to local state power and an ability to construct a common agenda of democratic participation and inclusive development (Baiocchi, 2005).

These historical and contemporary examples of substantive democracy at national and local scales should not, however, be seen as blueprint models that can be transferred to other contexts. The lesson is rather that substantial democratization requires democratic transformative politics, or in other words, the use of basic democratic institutions to pursue popular interests and to institutionalize deepened forms of representation (Stokke \& Törnquist, 2013; Törnquist \& Harriss, 2016). Moreover, contemporary challenges and setbacks - for example the growth of populism in Scandinavian countries and the problems of maintaining local models of empowered participatory governance in both Kerala and Brazil demonstrate how democratization is a continuous process of using political spaces and institutionalizing expanded spaces of participation (Baiocchi, Braathen, \& Teixeira, 2013; Baiocchi, Heller, \& Silva, 2011). Transformative democratic politics thus remains a timely political and analytical agenda in both old and new democracies, also for human geography.

\section{Conclusion}

The point of departure for this article has been the contemporary discourse on democratic decline and crisis, despite a global spread of electoral democracy in recent decades. These concerns are not primarily about the number of countries that are counted as democratic but rather a question of democratic substance. The article has thus advocated critical attention to the dynamics of democratization, especially the interplay between democratic institutions and democratic strategies and capacities of non-elite actors, alliances and strategies engaged in transformative democratic politics. This means that democratization should be conceived as a long-term and open-ended process, rather than a narrow process of designing formal electoral democracy. This is particularly important today, when there is a growing sense that 
democracy is in crisis and needs to be renewed and deepened in the face of non-democratic challenges.

\section{References}

Alexander, N. (2002). An Ordinary Country: Issues in the Transition from Apartheid to Democracy in South Africa. Pietermaritzburg: University of Natal Press.

Alexander, P. (2010). Rebellion of the poor: South Africa's service delivery protests - a preliminary analysis. Review of African Political Economy, 37, 25-40.

Aspinall, E. (2005). Opposing Suharto: Compromise, Resistance, and Regime Change in Indonesia. Stanford: Stanford University Press.

Aspinall, E., \& Mietzner, M. (Eds.). (2010). Problems of Democratisation in Indonesia: Elections, Institutions and Society. Singapore: Institute of Southeast Asian Studies.

Baiocchi, G. (2003). Radicals in Power. The Worker's Party (PT) and Experiments in Urban Democracy in Brazil. London: Zed.

Baiocchi, G. (2005). Militants and Citizens: The Politics of Participatory Democracy in Porto Alegre. Stanford: Stanford University Press.

Baiocchi, G., Braathen, E., \& Teixeira, A. C. (2013). Transformation Institutionalised? Making Sense of Participatory Democracy in the Lula Era. In K. Stokke \& O. Törnquist (Eds.), Democratization in the Global South: The Importance of Transformative Politics. Basingstoke: Palgrave-Macmillan.

Baiocchi, G., Heller, P., \& Silva, M. K. (2011). Bootstrapping Democracy: Transforming Local Governance and Civil Society in Brazil. Stanford: Stanford University Press.

Ballard, R., Habib, A., \& Valodia, I. (2006). Voices of Protest: Social Movements in PostApartheid South Africa. Pietermaritzburg: University of KwaZulu-Natal Press.

Barnett, C., \& Low, M. (Eds.). (2004). Spaces of Democracy: Geographical Perspectives on Citizenship, Participation and Representation. London: Sage.

Beetham, D. (1999). Democracy and Human Rights. Oxford: Polity Press.

Beetham, D. (2017). Democracy: Universality and diversity. Ethics \& Global Politics, 2(4), 284296.

Berman, S. (2006). The Primacy of Politics: Social Democracy and the Making of Europe's Twentieth Century. New York: Cambridge University Press.

Blaževič, I. (2016). The Challenges Ahead. Journal of Democracy, 27(2), 101-115.

Brandal, N., Bratberg, $\varnothing$., \& Thorsen, D. E. (2013). The Nordic Model of Social Democracy. Houndmills: Palgrave Macmillan.

Bridge, G. (2008). Global production networks and the extractive sector: Governing resourcebased development. Journal of Economic Geography, 8(389-419).

Brubaker, R. (2017). Why populism? Theory and Society, 46(5), 357-385.

Bünte, M. (2013). Burma's Transition to Quasi-Military Rule: from Rulers to Guardians? Armed Forces \& Society, 401(4), 742-764.

Bünte, M., \& Dosch, J. (2015). Myanmar: Political Reforms and the Recalibration of External Relations. Journal of Current Southeast Asian Affairs, 34(2), 3-19.

Call, C. T. (2008). The Fallacy of the 'Failed State'. Third World Quarterly, 29(8), 1491-1507. 
Carothers, T. (2002). The End of the Transition Paradigm. Journal of Democracy, 13(1), 5-21.

Carothers, T. (2006). Confronting the Weakest Link. Aiding Political Parties in New Democracies. Washington D.C.: Carnegie Endowment for International Peace.

Carothers, T. (2007a). How Democracies Emerge: The "Sequencing" Fallacy. Journal of Democracy, 18(1), 12-27.

Carothers, T. (2007b). Misunderstanding Gradualism. Journal of Democracy, 18(3), 18-27.

Carothers, T., \& De Gramont, D. (2013). Development Aid Confronts Politics: The Almost Revolution. Washington D.C.: Carnegie Endowment for International Peace.

Carothers, T., \& Youngs, R. (2017). Democracy is not dying: Seeing through the doom and gloom. Foreign Affairs, 11 April 2017.

Chandler, D. (2010). International Statebuilding: The Rise of Post-Liberal Governance. Oxon: Routledge.

Chatterjee, P. (2004). The Politics of the Governed: Reflections on Popular Politics in Most of the World. New York: Columbia University Press.

Cheesman, N., Farrelly, N., \& Wilson, T. (Eds.). (2014). Debating Democratization in Myanmar. Singapore: Institute of Southeast Asian Studies.

Cheesman, N., Skidmore, M., \& Wilson, T. (Eds.). (2012). Myanmar's Transition: Openings, Obstacles and Opportunities. Singapore: Institute of Southeast Asian Studies.

CIVICUS. (2018). State of Civil Society report 2018. London: CIVICUS World Alliance for Citizen Participation.

Collier, D., \& Levitsky, S. (1997). Democracy with Adjectives: Conceptual Innovations in Comparative Research. World Politics, 49(3), $430-451$.

Cornwall, A. (2004). Spaces for Transformation? Reflections on Issues of Power and Difference in Development. In S. Hickey \& G. Mohan (Eds.), Participation from Tyranny to Transformation? Exploring New Approaches to Participation in Development. London: Zed.

Cornwall, A. (Ed.) (2011). The Participation Reader. London: Zed.

della Porta, D. (2013). Can Democracy be Saved? Cambridge: Polity.

della Porta, D., \& Diani, M. (Eds.). (2015). The Oxford Handbook of Social Movements. Oxford: Oxford University Press.

Diamond, L., \& Plattner, M. F. (2015). Democracy in Decline? Baltimore: Johns Hopkins University Press.

Duffield, M. (2001). Global Governance and the New Wars: The Merging of Development and Security. London: Zed.

Edwards, M. (Ed.) (2011). The Oxford Handbook of Civil Society. New York: Oxford University Press.

Egreteau, R. (2016). Caretaking Democratization: The Military and Political Change in Myanmar. London: Hurst.

Egreteau, R., \& Jagan, L. (2013). Soldiers and Diplomacy in Burma: Understanding the Foreign Relations of the Burmese Praetorian State. Singapore: NUS Press.

Flinders, M., \& Wood, M. (Eds.). (2015). Tracing the Political: Depoliticisation, governance and the state. Bristol: Policy Press.

Flint, C. (Ed.) (2005). The Geography of War and Peace: From Death Camps to Diplomats. Oxford: Oxford University Press.

Ford, M., \& Pepinsky, T. B. (Eds.). (2014). Beyond Oligarchy: Wealth, Power, and Contemporary Indonesian Politics. Itacha: Cornell University, Southeast Asia Program Publications. 
Freedom House. (2018). Freedom in the World 2018. Washington D.C.: Freedom House. Fukuoka, Y. (2014). Debating Indonesia's Reformasi: Bridging "Parallel Universes". Journal of Contemporary Asia, 44(3), 540-552.

Fukuyama, F. (2014). Political Order and Political Decay. London: Profile.

Fung, A., \& Wright, E. O. (Eds.). (2003). Deepening Democracy: Institutional Innovations in Empowered Participatory Governance. London: Verso.

Glassman, J. (2007). Post-democracy. Environment and Planning A, 39(2037-2042).

Gleiss, M. S. (2017). Discourse, political space and the politics of citizenship. Norsk Geografisk Tidsskrift - Norwegian Journal of Geography, 71(4), 233-242.

Grugel, J., \& Bishop, M. L. (2014). Democratization: A Critical Introduction. New York: Palgrave-Macmillan.

Guelke, A. (2007). Dissecting the South African miracle: African parallels. Nationalism and Ethnic Politics, 2(1), 141-154.

Haarstad, H. (2007). Collective Political Subjectivity and the Problem of Scale. Contemporary Politics, 13(1), 57-74.

Hadiz, V. R., \& Chryssogelos, A. (2017). Populism in world politics: A comparative crossregional perspective. International Political Science Review, 38(4), 399-411.

Haggard, S., \& Kaufman, R. R. (2016). Democratization During the Third Wave. Annual Review of Political Science, 19(1), 125-144.

Harriss, J., Stokke, K., \& Törnquist, O. (Eds.). (2004). Politicising Democrazy: The New Local Politics of Democratisation. Basingstoke: Palgrave.

Heller, P. (2013). Participation and Democratic Transformation: Building Effective Citizenship in Brazil, India and South Africa. In K. Stokke \& O. Törnquist (Eds.), Democratization in the Global South: The Importance of Transformative Politics. Basingstoke: PalgraveMacmillan.

Hiariej, E., \& Stokke, K. (Eds.). (2017). Politics of Citizenship in Indonesia. Jakarta: Yayasan Pustaka Obor Indonesia.

Hickey, S., \& Mohan, G. (2004). Participation from Tyranny to Transformation? Exploring New Approaches to Participation in Development. London: Zed.

Holston, J. (2009). Insurgent Citizenship: Disjunctions of Democracy and Modernity in Brazil. Princeton: Princeton University Press.

Houtzager, P. P., \& Gurza Lavalle, A. (2010). Civil Society's Claims to Political Representation in Brazil. Studies in Comparative International Development, 45(1), 1-29.

Huang, R. L. (2013). Re-thinking Myanmar's political regime: military rule in Myanmar and implications for current reforms. Contemporary Politics, 19(3), 247-261.

Huntington, S. P. (1991). The Third Wave: Democratization in the Late Twentieth Century. Norman: University of Oklahoma Press.

IDEA. (2017). The Global State of Democracy 2017: Exploring Democracy's Resilience. Stockholm: Institute for Democracy and Electoral Assistance.

Ingram, A., \& Doods, K. (Eds.). (2016). Spaces of Security and Insecurity: Geographies of the War on Terror. London: Routledge.

Jarstad, A. K., \& Sisk, T. D. (Eds.). (2008). From War to Democracy. Dilemmas of Peacebuilding. Cambridge: Cambridge University Press.

Jones, L. (2014). Explaining Myanmar's regime transition: the periphery is central. Democratization, 21(5), 780-802.

Jones, P., \& Stokke, K. (Eds.). (2005). Democratising Development: The Politics of SocioEconomic Rights in South Africa. Leiden: Martinius Nijhoff. 
Jordhus-Lier, D. C. (2013). Trade Unions and Democratic Transformative Politics: Political Representation and Popular Mobilization during Local Government Reform in South Africa. In K. Stokke \& O. Törnquist (Eds.), Democratization in the Global South: The Importance of Transformative Politics. Basingstoke: Palgrave-Macmillan.

Karl, T. L. (1990). Dilemmas of Democratization in Latin America. Comparative Politics, 23(1), $1-21$.

Kobayashi, A. (Ed.) (2012). Geographies of War and Peace. London: Routledge.

Kriesi, H., \& Pappas, T. S. (2015). European Populism in the Shadow of the Great Recession. Colchester: ECPR Press.

Laclau, E., \& Mouffe, C. (1985). Hegemony and Socialist Strategy: Towards a Radical Democratic Politics. London: Verso.

Lall, M. (2016). Understanding Reform in Myanmar: People and Society in the Wake of Military Rule. London: Hurst.

Leitner, H., Peck, J., \& Sheppard, E. S. (Eds.). (2006). Contesting Neoliberalism: Urban Frontiers. New York: Guildford.

Levitsky, S., \& Way, L. A. (2010). Competitive Authoritarianism: Hybrid Regimes After the Cold War. Cambridge: Cambridge University Press.

Linz, J. J., \& Stepan, A. (1996). Problems of Democratic Transition and Consolidation: Southern Europe, South America, and Post-Communist Europe. Baltimore: The Johns Hopkins University Press.

Lipset, S. M. (1981). Political Man: The Social Bases of Politics (expanded edition). Baltimore: Johns Hopkins University Press.

Mahoney, J., \& Snyder, R. (1999). Rethinking Agency and Structure in the Study of Regime Change. Studies in Comparative International Development, Summer 1999, 3-32.

Mansfield, E. D., \& Snyder, J. L. (2007a). Electing to Fight: Why Democracies Go to War. Cambridge: MIT Press.

Mansfield, E. D., \& Snyder, J. L. (2007b). The "Sequencing" Fallacy. Journal of Democracy, 18(3), 5-10.

Marais, H. (2001). South Africa: Limits to Change. The Political Economy of Transition. London: Zed.

Mercer, C. (2002). NGOs, civil society and democratization: A critical review of the literature. Progress in Development Studies, 2(1), 5-22.

Millstein, M. (2017). Rights, identities and belonging: Reflections on the everyday politics of urban citizenship in Delft, Cape Town. Norsk Geografisk Tidsskrift - Norwegian Journal of Geography, 71(4), 253-267.

Miraftab, F., \& Wills, S. (2005). Insurgency and Spaces of Active Citizenship. Journal of Planning Education and Research, 25(2), 200-217.

Mohan, G. (2007). Participatory Development: From Epistemological Reversals to Active Citizenship. Geography Compass, 1(4), 779-796.

Moore, B. (1966). Social Origins of Dictatorship and Democracy: Lord and Peasant in the Making of the Modern World. Boston: Beacon Press.

Mouffe, C. (2005). On The Political. London: Routledge.

Mouffe, C. (2013). Agonistics: Thinking the World Politically. London: Verso.

Munck, G. L. (2015). Democratic Transitions. In N. J. Smelser \& P. B. Baltes (Eds.), International Encyclopedia of the Social \& Behavioral Sciences (2nd ed.). London: Elsevier.

Munck, G. L., \& Leff, C. S. (1997). Modes of Transition and Democratization: South America and Eastern Europe in Comparative Perspective. Comparative Politics, 29(3), 343-362. 
Nicholls, W., Miller, B., \& Beaumont, J. (Eds.). (2013). Spaces of Contention: Spatialities of Social Movements. Surrey: Ashgate.

O'Donnell, G., \& Schmitter, P. C. (1986). Transitions from Authoritarian Rule: Tentative Conclusions about Uncertain Democracies. Baltimore: Johns Hopkins University Press.

Ottaway, M. (2003). Democracy Challenged. The Rise of Semi-Authoritarianism. Washinton D.C.: Carnegie Endowment for International Peace.

Ottaway, M., \& Carothers, T. (Eds.). (2000). Funding Virtue: Civil Society Aid and Democracy Promotion. Washington D.C.: Carnegie Endowment for International Peace.

Paddison, R. (2009). Some reflections on the limitations to public participation in the postpolitical city. l'Espace Politique. https://journals.openedition.org/espacepolitique/1393\#authors.

Paris, R. (2004). At War's End: Building Peace After Civil Conflict. Cambridge: Cambridge University Press.

Paris, R., \& Sisk, T. D. (Eds.). (2009). The Dilemmas of Statebuilding: Confronting the Contradictions of Postwar Peace Operations. Abingdon: Routledge.

Pedersen, M. B. (2014). Myanmar's Democratic Opening: The Process and Prospect of Reform. In N. Cheesman, N. Farrelly, \& T. Wilson (Eds.), Debating Democratization in Myanmar. Singapore: Institute of Southeast Asian Studies.

Priyono, A. E., \& Törnquist, O. (Eds.). (2003). Indonesia's Post-Soeharto Democracy Movement. Jakarta: Demos.

Randall, V. (2007). Political Parties and Democratic Developmental States. Development Policy Review, 25(5), 633-652.

Randall, V., \& Svåsand, L. (2002). Party Institutionalization in New Democracies. Party Politics, $8(1), 5-29$.

Robison, R., \& Hadiz, V. R. (2004). Reorganising Power in Indonesia: The Politics of Oligarchy in an Age of Markets. London: RoutledgeCurzon.

Rueschemeyer, D., Stephens, H. E., \& Stephens, J. D. (1992). Capitalist Development and Democracy. Chicago: Chicago University Press.

Samadhi, W. P., \& Warouw, N. (Eds.). (2009). Building Democracy on the Sand: Advances and Setbacks in Indonesia. Yogyakarta: PCD Press.

Sandbrook, R., Edelman, M., Heller, P., \& Teichman, J. (2007). Social Democracy in the Global Periphery: Origins, Challenges, Prospects. Cambridge: Cambridge University Press.

Schmitter, P. C. (2010). Twenty-Five Years, Fifteen Findings. Journal of Democracy, 21(1), 1728.

Schmitter, P. C. (2015). Crisis and Transition, But Not Decline. Journal of Democracy, 26(1), 32-44.

Schmitter, P. C. (2017). The Role of Elites in Democratization. Journal of Chinese Political Science, 23(1), 33-46.

Schmitter, P. C., \& Karl, T. L. (1991). Modes of transition in Latin America, Southern and Eastern Europe. International Social Science Journal, 128(269-284).

Schumpeter, J. A. (1942). Capitalism, Socialism and Democracy. New York: Harper.

Seekings, J. (2000). The UDF: A History of the United Democratic Front in South Africa 19831991. Oxford: James Currey.

Sisk, T. (2013). Statebuilding. Cambridge: Polity.

Slater, D., \& Wong, J. (2013). The Strength to Concede: Ruling Parties and Democratization in Developmental Asia. Perspectives on Politics, 11(3), 717-733. 
Smith, A. M. (1998). Laclau and Mouffe: The Radical Democratic Imaginary. London: Routledge.

Stokke, K. (2009). Human Geography and the Contextual Politics of Substantive Democracy. Progress in Human Geography, 33(6), 739.742.

Stokke, K. (2017). Politics of citizenship: Towards an analytical framework. Norsk Geografisk Tidsskrift - Norwegian Journal of Geography, 71(4), 193-207.

Stokke, K., \& Törnquist, O. (Eds.). (2013). Democratization in the Global South: The Importance of Transformative Politics. Basingstoke: Palgrave-Macmillan.

Stokke, K., Vakulchuk, R., \& Øverland, I. (2017). Myanmar: A Political Economy Analysis. Oslo: Norwegian Institute of International Affairs.

Stradiotto, G. A., \& Guo, S. (2010). Transitional Modes of Democratization and Democratic Outcomes. International Journal on World Peace, 27(4), 5-40.

Swyngedouw, E. (2004). Globalisation or 'glocalization': Networks, territories and rescaling. Cambridge Review of International Affairs, 17(25-48).

The Economist. (2017). Democracy Index 2017: Free speech under attack. London: The Economist.

Tilly, C., \& Tarrow, S. (2007). Contentious Politics. Boulder: Paradigm Publishers.

Tomsa, D., \& Ufen, A. (Eds.). (2013). Party Politics in Southeast Asia: Clientelism and electoral competition in Indonesia, Thailand and the Philippines. London: Routledge.

Törnquist, O. (2013). Assessing Dynamics of Democratization: Transformative Politics, New Institutions, and the Case of Indonesia. New York: Palgrave Macmillan.

Törnquist, O., \& Harriss, J. (Eds.). (2016). Reinventing Social Democratic Development: Insights from Indian and Scandinavian Experiences. Copenhagen: NIAS Press.

Törnquist, O., Webster, N., \& Stokke, K. (Eds.). (2009). Rethinking Popular Representation. Basingstoke: Palgrave-Macmillan.

Van der Heijden, H.-A. (Ed.) (2014). Handbook of Political Citizenship and Social Movements. Cheltenham: Edward Elgar.

Wafer, A., \& Oldfield, S. (2015). Contesting the participatory sphere: Encountering the state in Johannesburg and Cape Town. In C. Bénit-Gbaffou (Ed.), Popular politics in South African cities: Unpacking community participation. Johannesburg: HSRC Press.

Webb, P., \& White, S. (Eds.). (2009). Party Politics in New Democracies. Oxford: Oxford University Press.

Wilson, J., \& Swyngedouw, E. (Eds.). (2014). The Post-Political and Its Discontents: Spaces of Depoliticisation of Radical Politics. Edinburgh: Edinburgh University Press.

Zakaria, F. (2007). The Future of Freedom: Illiberal Democracy at Home and Abroad. New York: W. W. Norton.

Zin, M. (2016). The New Configuration of Power. Journal of Democracy, 27(2), 116-131. 

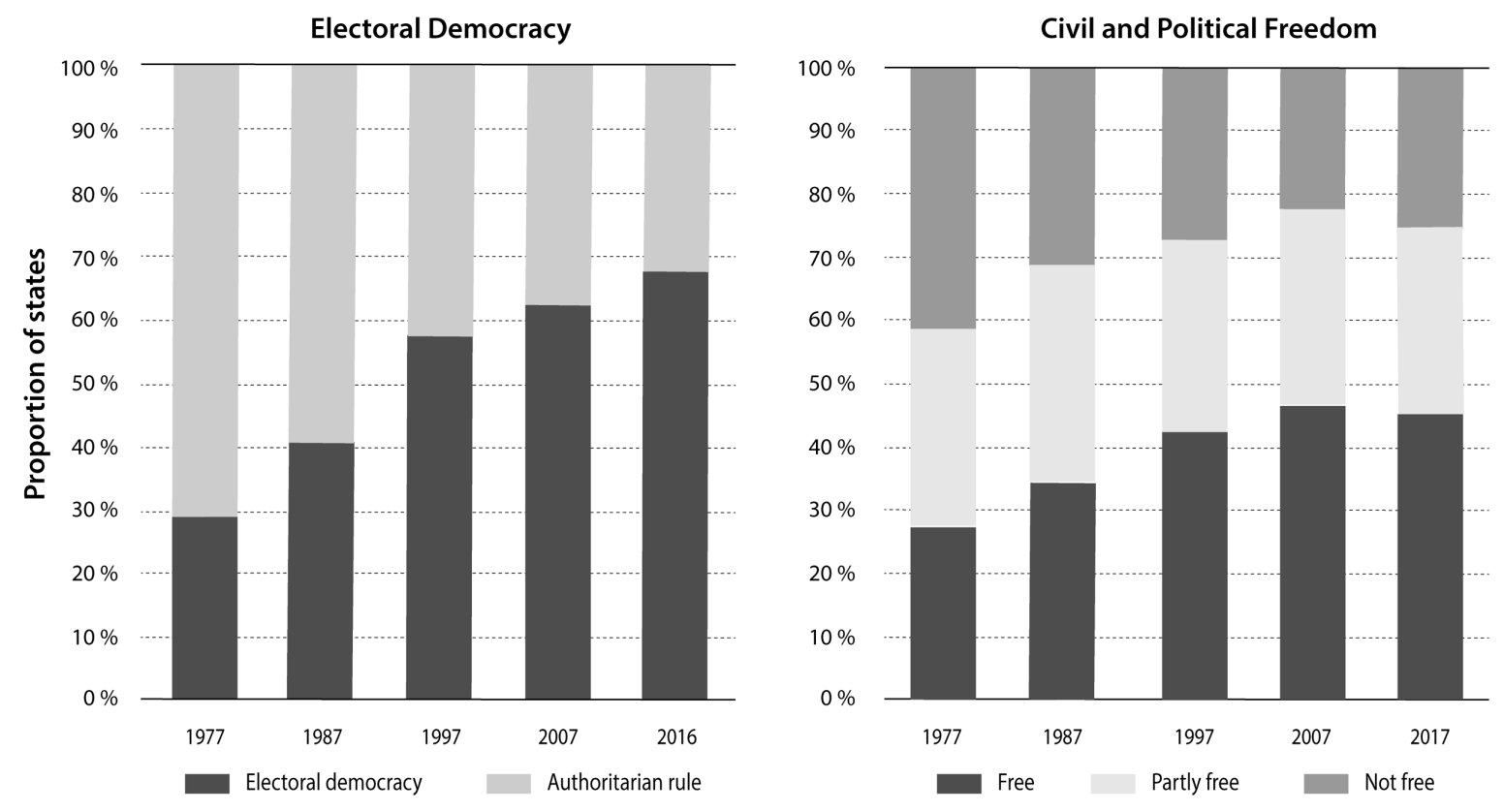

Figure 1. State of electoral democracy and civil/political freedom, 1977-2017 (data source: Freedom House, 2018; IDEA, 2017). 
Strategies of transition

Compromise

Force

$\begin{array}{llll}\begin{array}{l}\text { Relative } \\ \text { actor } \\ \text { strength }\end{array} & \text { Elite ascendant } & \text { Pact } & \text { Imposition } \\ & \text { Mass ascendant } & \text { Reform } & \text { Revolution }\end{array}$

Table 1. Ideal types of democratic transitions (source: Karl, 1990). 